\title{
Improving the Viability of Freeze-dried Probiotics Using a Lysine-based Rehydration Mixture
}

\author{
Karina Arellano ${ }^{1 \dagger}$, Haryung Park ${ }^{2 \dagger}$, Bobae $\mathrm{Kim}^{2}$, Subin $\mathrm{Yeo}^{2}$, Hyunjoo Jo ${ }^{3}$, Jin-Hak Kim ${ }^{4}$, Yosep Ji ${ }^{3}$, and \\ Wilhelm H. Holzapfel ${ }^{1,2 *}$ \\ ${ }^{1}$ Department of Advanced Convergence, ${ }^{2}$ HEM Inc., Business Incubator Center 103, Handong Global University, Pohang 37554, Republic of \\ Korea \\ ${ }^{3}$ HEM Inc., 404, Ace Gwanggyo Tower 3, Suwon 16229, Republic of Korea \\ ${ }^{4}$ COSMAXNS Inc., Seongnam 13486, Republic of Korea
}

Received: December 27, 2020 / Revised: February 25, 2021 / Accepted: February 27, 2021

\begin{abstract}
The probiotic market is constantly continuing to grow, concomitantly with a widening in the range and diversity of probiotic products. Probiotics are defined as live microorganisms that provide a benefit to the host when consumed at a proper dose; the viability of a probiotic is therefore of crucial importance for its efficacy. Many products undergo lyophilization for maintaining their shelf-life. Unfortunately, this procedure may damage the integrity of the cells due to stress conditions during both the freezing and (vacuum-) drying process, thereby impacting their functionality. We propose a lysine-based mixture for rehydration of freeze-dried probiotics for improving their viability during in vitro simulated gastric and duodenum stress conditions. Measurement of the zeta potential served as an indicator of cell integrity and efficacy of this mixture, while functionality was estimated by adhesion to a human enterocyte-like Caco-2 cell-line. The freeze-dried bacteria exhibited a significantly different zeta potential compared to fresh cultures; however, this condition could be restored by rehydration with the lysine mixture. Recovery of the surface charge was found to influence adhesion ability to the Caco-2 cell-line. The optimum lysine concentration of the formulation, designated "Zeta-bio", was found to be $0.03 \mathrm{M}$ for improving the viability of Lactiplantibacillus plantarum Lp-115 by up to $13.86 \%$ and a 7 -strain mixture (400B) to $41.99 \%$ compared to the control rehydrated with distilled water. In addition, the lysine Zeta-bio formulation notably increased the adherence ability of lyophilized Lp-115 to the Caco-2 cell-line after subjected to the in vitro stress conditions of the simulated gastrointestinal tract passage.
\end{abstract}

Keywords: Zeta potential, probiotic, viability, cell adhesion, L-lysine

\section{Introduction}

Probiotics are defined to have a beneficial impact on host health when administered in adequate amounts. Scientific evidence is steadily accumulating on the beneficial impact of probiotics on human health in various ways including the alleviation of immune disorders,

\footnotetext{
*Corresponding author

Tel: +82-10-8455-1360, Fax: +82-54-260-1319

E-mail: wilhelm@woodapple.net

${ }^{\dagger}$ These authors equally contributed to this work.
}

inflammatory bowel disease, type 2 diabetes and atherosclerosis [1-4]. Although recommendations tend to favor the consumption of high dose probiotics, neither the specific dosage nor the minimal viable numbers required for a putative probiotic strain are well-defined [5]. Strains with potential probiotic properties can be "naturally" obtained via fermented food such as fermented dairy products, yet the distribution of freeze-dried probiotic powders packaged in sachets or capsules are rapidly expanding in the market [6]. Marketed probiotics should be transportable, shelf-stable concentrates that guarantee the effects of intrinsic functional properties [7]. Com- 
mercialization of non-dairy probiotic products requires exact optimization of the final processing steps such as the harvesting, freezing and drying process [8]. The freeze-drying (a.k.a. lyophilization) process is known to be a stressful condition for live bacteria, yet this technology is still considered an appropriate approach to guarantee an extended shelf life for most probiotic products. The freeze-drying process is indeed a "challenge" to the viability of probiotic strains. Therefore, in order to maintain an effective dose, the number of bacteria in most products are generally three- to ten-fold higher compared to the numbers stated on the product label [5].

Key requirements for an effective probiotic include its survival under gastrointestinal stress conditions and its adhesion to the intestinal wall. Colon cell-lines may be used as an in vitro model for determining the adherence potential of a putative probiotic strain [9]. Adhesion properties of the bacterial cell envelope are determined by surface characteristics such as hydrophobicity, extracellular polymers (exopolysaccharides, adhesins) and the electric charge; at the same time the envelope plays a key role in the maintenance of cellular homeostasis and the support of intracellular functions [10-12]. During interactions with their environment bacteria are exposed to diverse physical forces that are transmitted by the specific surface structures to the cell [13]. Diverse functional acidic and basic groups such as phospholipids, lipopolysaccharides (LPS) on the membrane surface of Gram-negative bacteria and surface proteins, and hydrocarbon-like proteins such as lipoteichoic and teichoic acids on the cellular surface of Gram-positive bacteria will determine a strain's response to its environment [13, 14].

The electrostatic charge of the cell surface is considered to be a reflection of its functional groups. When in contact with a liquid the surface charge of a bacterial cell can be measured in millivolt units as zeta or electrokinetic potential; values for living cells are typically more negative than those for dead cells [15]. Both the cell surface composition and the properties of the surrounding medium (e.g., conductivity/ionic strength and $\mathrm{pH}$ ) will determine the cell's zeta potential [16]. Changes in the zeta potential (caused, e.g., by cationic agents) reflect membrane damage and alterations in permeability and may thus serve to predict cell viability [17]. Composition and chemical characteristics of the cell surface play a key role in its response to the surrounding medium (e.g., conductivity/ionic strength and $\mathrm{pH}$ ) and thereby in determining the electrostatic charge of the cell surface and its zeta potential [16]. Zeta potential can therefore be used as a measure of the electrical surface charge of a bacterial particle in a suspension [18]. It is determined by the nature of the groups exposed at the surface, and under normal physiological conditions bacteria are usually negatively charged due to the large amount of phosphate and carboxyl groups present on the cell surface [19]. Together with interfacial viscoelasticity and tension the zeta potential can serve to characterize the surface properties of intestinal bacteria and to predict their adhesion potential in the GI tract [20].

The zeta potential around bacteria can thus serve as an indicator of their viability, integrity and efficacy especially in terms of overall and physiological potential [21]. We therefore propose a new approach for sachet packaged probiotics containing the probiotic together with a special lysine-based formulation for supporting the re-activation of a probiotic strain in water. We have named this mixture "Zeta-bio" since the zeta potential was used as an initial screening factor for 33 different chemicals using three representative strains [(Lactiplantibacillus (Lp.) plantarum Lp-115, Lacticaseibacillus. (Lc.) casei Lc-11 and Bifidobacterium longum Bl-05)] from a commercial 7 strain mixture (400B). This mixture also contained Lactobacillus acidophilus La-14, Streptococcus thermophilus St-2, Bifidobacterium animalis subsp. lactis Bl04 and $B$. breve Bb-03. Optimization of the lysine concentration for the 7-strain mixture (400B) and the commercial strain Lp. plantarum LP-115 was further studied using the simulated stomach duodenum passage (SSDP) in vitro model and cell adhesion as the key parameters.

\section{Material and Methods}

\section{Microorganisms}

Lp. plantarum Lp-115 and Lc. casei Lc-11 were cultivated in MRS broth (BD, USA) at $37^{\circ} \mathrm{C}$ for $18 \mathrm{~h}$. $B$. longum Bl-05 was cultivated in BL broth (BD) with 5\% bovine blood at $37^{\circ} \mathrm{C}$ for $18 \mathrm{~h}$ under anaerobic conditions (Anaerobic Chamber Whitley DG250, Don Whitley Scientific, UK). Initially, $1 \%(\mathrm{v} / \mathrm{v})$ of each strain was activated in either $5 \mathrm{ml}$ MRS broth or BL broth and propagated by two sub-culturing steps in MRS broth 
Table 1. Concentrations of ingredients combined for the potential Zeta-bio formulation.

\begin{tabular}{cccccc}
\hline Ingredients (Brand) & LP/Mix-1 & LP/Mix-2 & LP/Mix-3 & LP/Mix-4 & LP/Mix-5 \\
\hline L-lysine hydrochloride (Samin) & $0.182 \mathrm{~g}(0.01 \mathrm{M})$ & $0.364 \mathrm{~g}(0.02 \mathrm{M})$ & $0.546 \mathrm{~g}(0.03 \mathrm{M})$ & $0.728 \mathrm{~g}(0.04 \mathrm{M})$ & $0.910 \mathrm{~g}(0.05 \mathrm{M})$ \\
FOS (Hi-tech) & $3.5 \mathrm{~g}$ & $3.5 \mathrm{~g}$ & $3.5 \mathrm{~g}$ & $3.5 \mathrm{~g}$ & $3.5 \mathrm{~g}$ \\
Microorganism & $0.15 \mathrm{~g}$ & $0.15 \mathrm{~g}$ & $0.15 \mathrm{~g}$ & $0.15 \mathrm{~g}$ & $0.15 \mathrm{~g}$ \\
& $\left(2 \times 10^{11} \mathrm{CFU} / \mathrm{g}\right)$ & $\left(2 \times 10^{11} \mathrm{CFU} / \mathrm{g}\right)$ & $\left(2 \times 10^{11} \mathrm{CFU} / \mathrm{g}\right)$ & $\left(2 \times 10^{11} \mathrm{CFU} / \mathrm{g}\right)$ & $\left(2 \times 10^{11} \mathrm{CFU} / \mathrm{g}\right)$ \\
Dextrin (Daesang) & $6.204 \mathrm{~g}$ & $6.130 \mathrm{~g}$ & $5.912 \mathrm{~g}$ & $5.766 \mathrm{~g}$ & $5.62 \mathrm{~g}$ \\
Total & $10 \mathrm{~g}$ & $10 \mathrm{~g}$ & $10 \mathrm{~g}$ & $10 \mathrm{~g}$ & $10 \mathrm{~g}$ \\
\hline
\end{tabular}

before each experiment.

All strains and freeze-dried probiotics including COSMAX NBT (400B) 7-strain HRB and its materials (Table 1) were provided by COSMAX NBT Inc. (Korea). Each probiotics sachet contained $3 \times 10^{10} \mathrm{CFU}$ of the freeze-dried microorganism mix with $3.5 \mathrm{~g}$ of fructooligosaccharides (FOS) and dextrin (Table 1).

\section{Zeta potential screening test}

The lyophilized probiotic powders of $L p$. plantarum Lp-115, Lc. casei Lc-11 and B. longum Bl-05 were respectively transferred at a concentration of $1 \times 10^{9}$ $\mathrm{CFU} / \mathrm{g}$ to a $50 \mathrm{ml}$ tube and mixed with $0.1 \mathrm{~g}$ of each 33 different chemicals in the ingredient list (Table 2). These three strains were the major representatives of the mixture and comprised $>60 \%$ of the total viable numbers (data provided by COSMAX NBT Inc.). The weight of each formulation varied according to the composition when matched to the final concentration 0.1 M. The 33 chemicals were selected according to the "Food Additive Status List" provided by the Food and Drug Administration (FDA, USA). One milliliter of deionized distilled water (DDW) was added to the freeze-dried strain and the single chemical mixture and rehydrated for $1 \mathrm{~min}$ at $25^{\circ} \mathrm{C}$. Subsequently $9 \mathrm{ml}$ of DDW at $\mathrm{pH} 2.5$ were added to each sample and the $\mathrm{pH}$ re-adjusted using $0.1 \mathrm{~N} \mathrm{HCl}$, and $800 \mu \mathrm{l}$ of the calibrated sample were transferred to DTS1070 cuvettes. The electrophoretic mobility was measured by the Zetasizer Nano ZEN 3600 (Malvern Panalytica, UK) after $2 \mathrm{~min}$ of equilibration time and the Smoluchowski equation was used to convert the data into zeta potential values. Each value represented the average of three reads.

\section{Simulated stomach duodenum passage (SSDP) test}

The potential of Zeta-bio formulations (Table 1) for the activation, adhesion and protection of freeze-dried $L p$. plantarum Lp-115 and the 7-strain mixture (400B) was evaluated using the in vitro SSDP according to Ji et al. [22] with some modifications. The screening of the formulations showed superior protection by lysine to be this was further analyzed for determining the optimal lysine concentration for supporting bacterial cell viability within the of $0.01 \mathrm{M}$ to $0.05 \mathrm{M}$, also considering possible adverse taste-effects in the product. The sample mixture was prepared according to Table $1 \mathrm{in} 1 \mathrm{ml}$ of distilled water at $25^{\circ} \mathrm{C}$ and mixed for $1 \mathrm{~min}$. After $1 \mathrm{~min}$ $9 \mathrm{ml}$ of sterile phosphate buffer saline 1X (PBS, USA) at pH 2.5 were added to each sample. The tubes were incubated at $37^{\circ} \mathrm{C}$ and subjected to low $\mathrm{pH}$ gastric stress for $1 \mathrm{~h}$. This was directly followed by exposure to $4 \mathrm{ml}$ of a bile salts solution (10\% oxgall; Becton, Dickinson and Company - BD) and $17 \mathrm{ml}$ of synthetic duodenum juice at pH $6.0\left(\mathrm{NaHCO}_{3}: 6.4 \mathrm{~g} / \mathrm{l}, \mathrm{KCl}: 0.239 \mathrm{~g} / \mathrm{l}\right.$ and $\mathrm{NaCl}$ : $1.28 \mathrm{~g} / \mathrm{l})$ thereby simulating the small intestinal passage for two hours. During the GI-tract assay samples were taken at 0,1 , and $3 \mathrm{~h}$ incubation time $(\mathrm{t}=0,1$ and 2$)$ to calculate the probiotic survivability after gastric stress and bile stress, respectively, by plate counting viable colonies on MRS and BL (BD) agar. The plates were incubated under anaerobic conditions at $37^{\circ} \mathrm{C}$ for $48 \mathrm{~h}$.

\section{Cell adhesion for the validation of the effect of lysine}

Lp. plantarum Lp-115, Lc. casei Lc-11, B. longum Bl-05 and the 7-strain mixture (400B) were tested for their ability to adhere to the human enterocyte-like Caco- 2 cell-line (distributed by the Korean Cell Line Bank). The cells were grown and maintained in Minimal Essential Medium (MEM, USA, SH30024.01) with 10\% Fetal Bovine Serum (Gibco, Thermo Fisher Scientific, USA), 1\% non-essential amino acids (Gibco), and 1\% of antibiotics (Antibiotic-antimycotic, Gibco) at $36.5^{\circ} \mathrm{C}$ and 
Table 2. List of ingredients tested for their zeta potential activity.

\begin{tabular}{|c|c|c|c|c|c|}
\hline Ingredient & Chemical formula & $\begin{array}{l}\text { Molecular weight } \\
(\mathrm{g} / \mathrm{mol})\end{array}$ & Purity (\%) & Brand & Lot no. \\
\hline \multicolumn{6}{|c|}{ Carbohydrates } \\
\hline Arabinose & $\mathrm{C}_{5} \mathrm{H}_{10} \mathrm{O}_{5}$ & 150.13 & 100 & USB & 70047 \\
\hline Xylose & $\mathrm{C}_{5} \mathrm{H}_{10} \mathrm{O}_{5}$ & 150.1 & 99 & Sigma & 053K00131 \\
\hline Rhamnose & $\mathrm{C}_{6} \mathrm{H}_{12} \mathrm{O}_{5} \cdot \mathrm{H}_{2} \mathrm{O}$ & 182.2 & 99 & Sigma & 058K0695 \\
\hline Fructose & $\mathrm{C}_{6} \mathrm{H}_{12} \mathrm{O}_{6}$ & 180.16 & 100 & Sigma & $125 K 01611$ \\
\hline Mannitol & $\mathrm{C}_{6} \mathrm{H}_{14} \mathrm{O}_{6}$ & 182.17 & 100 & Sigma & 034K0061 \\
\hline Sucrose & $\mathrm{C}_{12} \mathrm{H}_{22} \mathrm{O}_{11}$ & 342.3 & 100 & Daejung & S0784RE1 \\
\hline Sorbitol & $\mathrm{C}_{6} \mathrm{H}_{14} \mathrm{O}_{6}$ & 182.17 & 97 & Daejung & S0503QC1 \\
\hline Glucose & $\mathrm{C}_{6} \mathrm{H}_{12} \mathrm{O}_{6}$ & 180.16 & 99.5 & Sigma & SLBS2877V \\
\hline Maltose & $\mathrm{C}_{12} \mathrm{H}_{22} \mathrm{O}_{11} \cdot \mathrm{H}_{2} \mathrm{O}$ & 360.31 & 100 & USB & 109469 \\
\hline Trehalose & $\mathrm{C}_{12} \mathrm{H}_{22} \mathrm{O}_{11} \cdot 2 \mathrm{H}_{2} \mathrm{O}$ & 378.33 & 99 & Sigma & SLBV3123 \\
\hline Fructooligosaccharide & $\mathrm{C}_{6} \mathrm{H}_{12} \mathrm{O}_{6}$ & - & 95 & Qhtbio & 10002428 \\
\hline \multicolumn{6}{|c|}{ Amino acids } \\
\hline L-Arginine & $\mathrm{C}_{6} \mathrm{H}_{14} \mathrm{~N}_{4} \mathrm{O}_{2}$ & 174.2 & 98 & Sigma & 017K0664 \\
\hline L-Tryptophan & $\mathrm{C}_{11} \mathrm{H}_{12} \mathrm{~N}_{2} \mathrm{O}_{2}$ & 204.23 & 99 & Kanto chemical co. & $403 N 2187$ \\
\hline L-Phenylalanine & $\mathrm{C}_{9} \mathrm{H}_{11} \mathrm{NO}_{2}$ & 165.19 & 99 & Junsei & 2012L1433 \\
\hline L-Ornithine & $\mathrm{C}_{5} \mathrm{H}_{12} \mathrm{~N}_{2} \mathrm{O}_{2} \cdot \mathrm{ClH}$ & 168.62 & 99 & Sigma & $109 K 1468$ \\
\hline L-Glutamic acid & $\mathrm{C}_{5} \mathrm{H}_{8} \mathrm{NNaO}_{4} \cdot \mathrm{xH}_{2} \mathrm{O}$ & 169.11 & 99 & Sigma & SLBF7449V \\
\hline L-Proline & $\mathrm{C}_{5} \mathrm{H}_{9} \mathrm{NO}_{2}$ & 115.1 & 100 & Sigma & $72 \mathrm{H} 0774$ \\
\hline L-Lysine hydrochloride & $\mathrm{C}_{6} \mathrm{H}_{14} \mathrm{~N}_{2} \mathrm{O}_{2} \cdot \mathrm{HCl}$ & 182.65 & 98 & Sigma & $108 \mathrm{~K} 1321$ \\
\hline L-Serine & $\mathrm{C}_{3} \mathrm{H}_{7} \mathrm{NO}_{3}$ & 105.09 & 99 & Georgiachem & S454621R \\
\hline L-Threonine & $\mathrm{C}_{4} \mathrm{H}_{9} \mathrm{NO}_{3}$ & 119 & 99 & Georgiachem & T262958H \\
\hline L-Aspartic acid & $\mathrm{C}_{4} \mathrm{H}_{7} \mathrm{NO}_{4}$ & 133.1 & 99 & Georgiachem & A977123A \\
\hline L-Tyrosine & $\mathrm{C}_{9} \mathrm{H}_{11} \mathrm{NO}_{3}$ & 181.19 & 99 & Samchun chemicals & 101917 \\
\hline L-Histidine & $\mathrm{C}_{6} \mathrm{H}_{9} \mathrm{~N}_{3} \mathrm{O}_{2}$ & 209.64 & 99 & Daejung & H2821RL1 \\
\hline \multicolumn{6}{|c|}{ Salts } \\
\hline Sodium phosphate & $\mathrm{Na}_{2} \mathrm{HPO}_{4}$ & 141.96 & 99 & Sigma & 075K2520 \\
\hline Sodium L-tartrate dihydrate & $\mathrm{C}_{4} \mathrm{H}_{4} \mathrm{Na}_{2} \mathrm{O}_{6} \cdot 2 \mathrm{H}_{2} \mathrm{O}$ & 230.08 & 99 & Sigma & 07425BC \\
\hline Sodium bicarbonate & $\mathrm{NaHCO}_{3}$ & 84 & 99.8 & Yakuri & 312132812 \\
\hline \multicolumn{6}{|c|}{ Organic acids } \\
\hline Malic acid & $\mathrm{C}_{4} \mathrm{H}_{6} \mathrm{O}_{5}$ & 134 & 98 & Sigma & SLBS7651 \\
\hline Pyruvic acid & $\mathrm{C}_{3} \mathrm{H}_{4} \mathrm{O}_{3}$ & 80.06 & 100 & Daejung & P3470SG1 \\
\hline \multicolumn{6}{|c|}{ Osmolytes } \\
\hline Betaine & $\mathrm{C}_{5} \mathrm{H}_{11} \mathrm{NO}_{2}$ & 117 & 98 & Daejung & B1549PE1 \\
\hline Taurine & $\mathrm{C}_{2} \mathrm{H}_{7} \mathrm{NO}_{3} \mathrm{~S}$ & 125.15 & 99 & Sigma & 12515DU \\
\hline \multicolumn{6}{|c|}{ Vitamins } \\
\hline Riboflavin & $\mathrm{C}_{17} \mathrm{H}_{20} \mathrm{~N}_{4} \mathrm{O}_{6}$ & 376.37 & 100 & Sigma & $069 k 1585$ \\
\hline Thiamine hydrochloride & $\mathrm{C}_{12} \mathrm{H}_{17} \mathrm{ClN}_{4} \mathrm{OS} . \mathrm{HCl}$ & 337.27 & 98 & Daejung & T0027QL1 \\
\hline L-Ascorbic acid & $\mathrm{C}_{6} \mathrm{H}_{8} \mathrm{O}_{6}$ & 176.12 & 99 & $\mathrm{TCl}$ & KNBGE \\
\hline
\end{tabular}

$5 \% \mathrm{CO}_{2}$. The bacterial adhesion assay was performed according to Botes et al. [23] with some modifications.
The lyophilizates $\left(3 \times 10^{8} \mathrm{CFU}\right)$ of the 3 strains and the 7 -strain bacterial mixture were reactivated in $10 \mathrm{ml}$ of 
$0.03 \mathrm{M}$ lysine or proline for $5 \mathrm{~min}$. Hundred microliter of each bacterial suspension were incubated together with a Caco-2 monolayer at 10:1 (bacteria: cell ratio) for $1.5 \mathrm{~h}$. After incubation, the bacteria were withdrawn by suctioning, and the cells washed two times with ice-cold PBS to remove the non-attached bacteria and then lysed with $400 \mu \mathrm{l}$ of TrypLE (Gibco) for $15 \mathrm{~min}$ at $37^{\circ} \mathrm{C}$ and $600 \mu \mathrm{l}$ of MEM that were subsequently added. To quantify the number of bacteria associated with the Caco-2/ TC-7 cells the samples were serially diluted and counted on MRS agar plates after $48 \mathrm{~h}$ at $37^{\circ} \mathrm{C}$. All the experimental results were triplicated. For Lp-115 and the 7strain mixture (400B), the products were adjusted to $2 \times 10^{8} \mathrm{CFU} / \mathrm{g}$ and re-activated in the Zeta-bio formulation with the different concentrations of lysine (0.03 M$0.05 \mathrm{M}$ ) resuspended in $1 \mathrm{ml}$ of distilled water (DW). All strains were subjected to the SSDP test and harvested at $3000 \mathrm{~g}$ for $20 \mathrm{~min}$ to remove the components related to the stomach and duodenum conditions plus bile salts. The pellets were washed three times with $1 \mathrm{x}$ PBS and resuspended in $10 \mathrm{ml}$ MEM cell culture media with $20 \%$ FBS, $2 \mathrm{mM}$ glutamine and $1 \%$ non-essential amino acids. The rest of the process were identical to the initial lysine cell adhesion experiment given above.

\section{Results}

\section{Screening of 33 chemical ingredients based on zeta potential}

Measurement of the zeta potential was used to screen the effect of 33 chemical ingredients on three representative bacterial strains of the 7-strain mixture (400B): $L p$. plantarum Lp-115, Lc. casei Lc-11 and B. longum Bl-05. Lyophilization appeared to result in a significant depolarization of the B. longum $\mathrm{Bl}-05$ cells compared to the freshly cultivated cells (Fig. 1A). However, changes in the zeta potential charge were not observed in the $L p$. plantarum Lp-115 and Lc. casei Lc-11 strains and opposite tendencies were detected (Figs. 1B and C). Most of the amino acids had a significant impact on the positive change of the zeta potential of all three strains (Fig. 1). However, only lysine produced a negative zeta potential for all three strains including B. longum Bl-05 (Fig. $1 \mathrm{~A}$ ). Therefore, the effect of lysine was further validated by the cell adhesion test and proline which portrayed the opposite effect of lysine or in the case of $\mathrm{Lp}$. plantarum Lp-115 showed extremely negative zeta potential (mV) values was also included to determine whether the zeta potential would affect the cell adhesion capability.
A

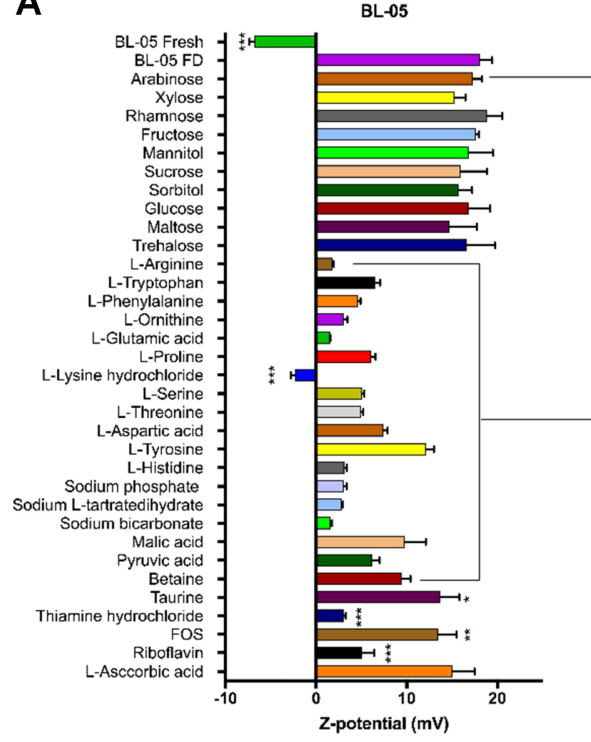

B

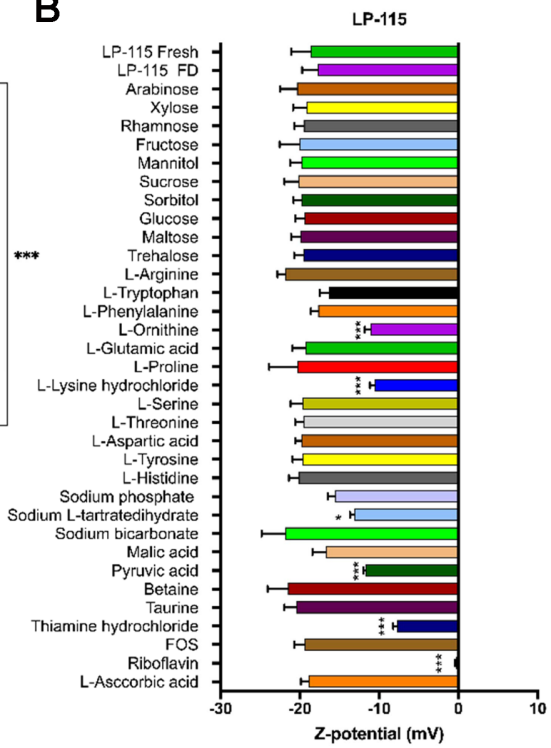

C

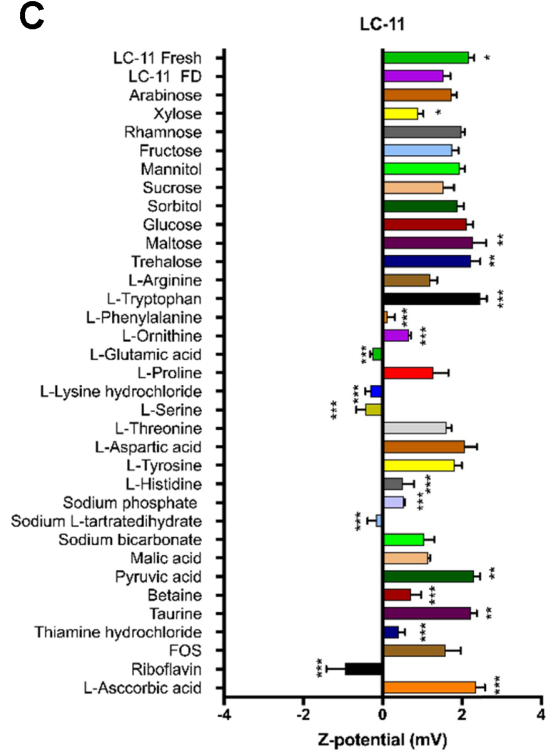

Fig. 1. Effect of 33 ingredients on the zeta potential of different probiotic strains within the 7-strain mixture (400B). Three representative strains of the 7-strain mixture (400B) were used to screen for the most optimal ingredient for the hyperpolarization of the zeta potential. (A) BL-05: Bifidobacterium longum BI-05, (B) LP 115: Lactiplantibacillus plantarum Lp-115, (C) LC-11: Lacticaseibacillus casei LC-11. Statistical analysis was performed using one-way ANOVA compared to each strain's freeze-dried (FD) sample. ${ }^{*} p<0.05,{ }^{* *} p<0.01,{ }^{* * *} p<0.001$ by Dunnett's test. 


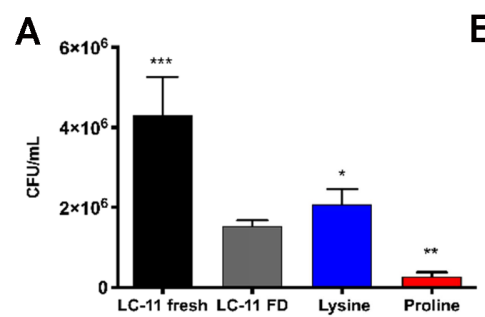

E

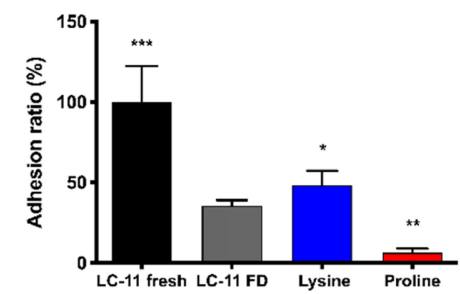

B

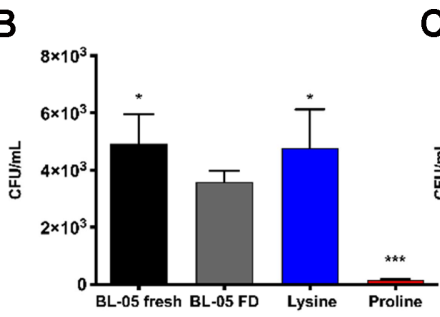

$\mathbf{F}$

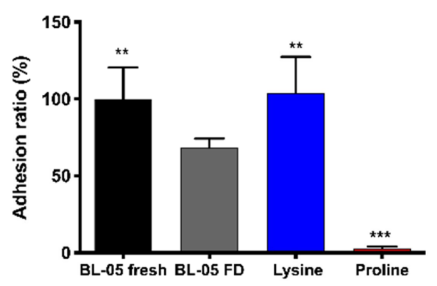

C

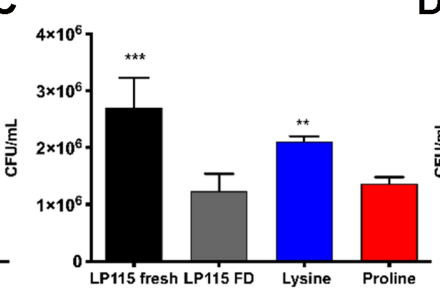

G

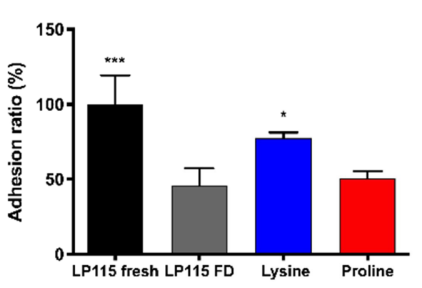

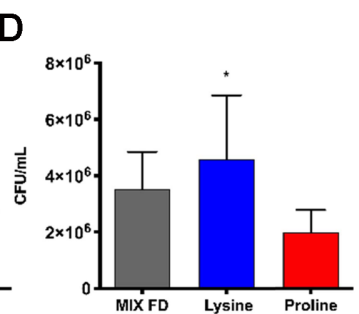

$\mathrm{H}$

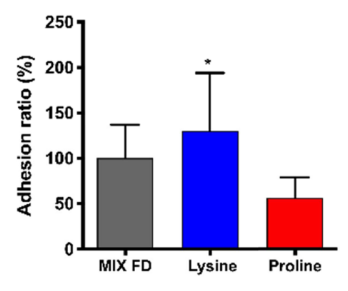

Fig. 2. Cell adhesion results of fresh, freeze-dried and freeze-dried cells following reactivation in $10 \mathrm{ml}$ of $0.03 \mathbf{M}$ lysine or proline for 5 min. (A, E) Lacticaseibacillus casei Lc-11; (B, F) Bifidobacterium longum Bl-05; (C, G) Lactiplantibacillus plantarum Lp-115 $(D, H)$ 7-strain mixture (400B). Statistical analysis was performed using one-way ANOVA compared to each strain's freeze-dried (FD) sample. ${ }^{*} p<0.05,{ }^{* *} p<0.01,{ }^{* * *} p<0.001$ by Fisher's LSD test.

Freshly cultivated and freeze-dried bacterial suspensions of each strain were used as positive and negative controls to compare the effect of lysine and proline on the cell adhesion of the freeze-dried bacteria. Freezedried Lc. casei Lc-11 (Figs. 2A and E), Lp. plantarum Lp-115 (Figs. 2C and G) and B. longum Bl-05 (Figs. 2B and $\mathrm{F}$ ) showed a significantly lower attachment to the Caco-2/TC-7 cell-line compared to the fresh cells. However, the selected chemical, lysine, significantly recovered the cell adhesive property of the bacterial cells when compared to the freeze-dried form (Fig. 2) whereas proline had a significantly opposite effect (Fig. 2). Proline, which induced an extremely negative zeta potential in $L p$. plantarum Lp-115 did not have any significant affect in the adhesion ability of its freeze-dried cells (Figs. 2C and G). This result was also reflected in the 7-strain mix (400B) (Figs. 2D and H).

\section{Selection of optimal lysine concentration through SSDP and cell adhesion}

Based on the analysis of viability and cell adhesion, the two key parameters that are known to be influenced by the zeta potential, the optimal concentration of lysine was selected. The concentration of the lysine-based Zetabio formula was reduced to $0.01-0.05 \mathrm{M}$, considering the taste effect for the final product formulation (Table 1).
Further analysis was conducted using the actual commercial products: 7 -strain mixture (400B) and the single cell probiotic, Lp. plantarum Lp-115.

SSDP was performed to check the effect of the different concentrations of lysine in the Zeta-bio formulation on the viability of the freeze-dried bacteria after simulated passage of the stomach and duodenum. The viability of the freeze-dried form of $L$ p. plantarum Lp- 115 significantly decreased after SSDP compared to the fresh control. Compared to the control, a lysine concentration of $\geq 0.03 \mathrm{M}$ in the Zeta-bio formulation supported a significantly higher viability both after the stomach (>43\%) and duodenum stress (>11\%) for Lp. plantarum Lp-115. This tendency was also found to be true for the 7-strain mixture (400B) in which the survival rate after the stomach and duodenum stress was higher at $0.03 \mathrm{M}$ lysine concentration with respective values was above $50.09 \%$ and $41.99 \%$, respectively (Table 3). For the cell adhesion test the three concentrations of lysine: $0.03 \mathrm{M}$, $0.04 \mathrm{M}$, and $0.05 \mathrm{M}$, were therefore chosen according to the final viability after the SSDP procedure.

The different lysine concentrations strongly influenced the adherence ability of the freeze-dried bacteria to the intestinal Caco-2 cell-line. Compared to the freshly cultivated culture the freeze-dried cells of $L p$. plantarum Lp115 showed significantly lower adhesion. However, the 
Table 3. Effects of lysine concentration in the Zeta-bio formulation on survival during simulated stomach-duodenum passage (SSDP).

\begin{tabular}{|c|c|c|c|c|c|c|c|}
\hline \multirow[b]{2}{*}{ Sample name } & \multirow[b]{2}{*}{ Strain } & \multirow{2}{*}{$\begin{array}{c}\text { Lysine } \\
\text { concentration }\end{array}$} & \multirow{2}{*}{$\frac{\text { Initial }}{\log \mathrm{CFU} / \mathrm{ml}}$} & \multicolumn{2}{|c|}{ Stomach } & \multicolumn{2}{|c|}{ Duodenum } \\
\hline & & & & $\log \mathrm{CFU} / \mathrm{ml}$ & $\begin{array}{c}\text { Survival } \\
\text { (\%) }\end{array}$ & $\log$ CFU/ml & $\begin{array}{c}\text { Survival } \\
(\%)\end{array}$ \\
\hline Lp-115 fresh & & none & $8.21 \pm 0.10$ & $8.05 \pm 0.26$ & 64.45 & $7.61 \pm 0.15$ & $25.76^{* * * *}$ \\
\hline Lp-115 FD & & none & $8.04 \pm 0.16$ & $4.15 \pm 0.16$ & 0.01 & $4.02 \pm 0.66$ & 0.02 \\
\hline LP-1 & Lactiplantibacillus & $0.01 \mathrm{M}$ & $7.05 \pm 0.21$ & $5.63 \pm 0.05$ & 5.07 & $4.29 \pm 0.28$ & $0.17^{* * *}$ \\
\hline LP-2 & plantarum & $0.02 \mathrm{M}$ & $8.46 \pm 0.04$ & $6.97 \pm 0.01$ & 4.25 & $6.26 \pm 0.01$ & $0.63^{* * *}$ \\
\hline LP-3 & Lp-115 & $0.03 \mathrm{M}$ & $8.59 \pm 0.03$ & $8.28 \pm 0.08$ & 48.64 & $7.73 \pm 0.01$ & $13.86^{* * *}$ \\
\hline LP-4 & & $0.04 \mathrm{M}$ & $8.62 \pm 0.02$ & $8.30 \pm 0.00$ & 48.01 & $7.69 \pm 0.00$ & $11.93 * * *$ \\
\hline LP-5 & & $0.05 \mathrm{M}$ & $8.63 \pm 0.09$ & $8.26 \pm 0.01$ & 43.20 & $7.72 \pm 0.03$ & $12.17^{* * *}$ \\
\hline Mix FD & & none & $8.75 \pm 0.02$ & $7.52 \pm 0.05$ & 6.01 & $4.96 \pm 0.07$ & 0.02 \\
\hline Mix-1 & & $0.01 \mathrm{M}$ & $8.20 \pm 0.08$ & $6.43 \pm 0.00$ & 1.74 & $5.88 \pm 0.06$ & $0.48^{* * *}$ \\
\hline Mix-2 & 7 strain mixture & $0.02 \mathrm{M}$ & $8.42 \pm 0.01$ & $7.79 \pm 0.01$ & 23.02 & $7.69 \pm 0.04$ & $18.70 * *$ \\
\hline Mix-3 & (400B) & $0.03 \mathrm{M}$ & $8.32 \pm 0.01$ & $8.02 \pm 0.01$ & 50.09 & $7.94 \pm 0.05$ & $41.99 * *$ \\
\hline Mix-4 & & $0.04 \mathrm{M}$ & $8.33 \pm 0.03$ & $7.95 \pm 0.03$ & 41.93 & $7.90 \pm 0.01$ & $37.65 *$ \\
\hline Mix-5 & & $0.05 \mathrm{M}$ & $8.37 \pm 0.01$ & $8.10 \pm 0.01$ & 53.33 & $7.82 \pm 0.14$ & $28.72 *$ \\
\hline
\end{tabular}

The data are shown as mean \pm standard deviation. Statistical analysis for the Lp-115 was performed by student's t-test compared to each product's freeze-dried (FD) sample. ${ }^{*} p<0.05,{ }^{* *} p<0.01,{ }^{* * *} p<0.001$.

cell adhesion ratio for $\mathrm{Lp}$. plantarum Lp-115 was best recovered through the $0.03 \mathrm{M}$ lysine Zeta-bio formulation. As the concentration of lysine was increased beyond $0.03 \mathrm{M}$ the cell adhesion ratio decreased accordingly for Lp. plantarum Lp-115 (Figs. 3A and B). This tendency was also portrayed in the SSDP test of $L p$. plantarum Lp-115 with $0.03 \mathrm{M}$ showing the highest viability of $48.64 \%$ and $13.86 \%$ after both the stomach stress and bile stress (Table 3), respectively. The 7strain mixture (400B), on the other hand, gave significantly higher adhesion ratios for both $0.03 \mathrm{M}$ and $0.04 \mathrm{M}$ lysine Zeta-bio formulations (Figs. 3C and D).

\section{Discussion}

Preserving the integrity of the cell envelope, and particularly of the plasma membrane, is important in maintaining cell viability and homeostasis. Adhesive potential may be considered as a criterion for reflecting functionality of an effective potential probiotic. Successful survival after gastric stress and proper attachment to the intestinal cells will promote immunomodulatory and metabolic functions, and thereby serve to strengthen the gut barrier and competitively inhibit the adhesion of pathogens [24]. Key adhesive factors on the cell surface of Gram-positive bacteria include lipoteichoic acid, surface layer proteins and mucous binding proteins [25]. Although the process of lyophilization helps to maintain bacterial shelf-life by the reduction of water activity, it also may disrupt the cell membrane thereby leading to the loss of its original functionality [26]. Recovering the integrity of the cell membrane may help reactivate its functionality through increase in viability and cell adhesive properties.

The depolarization of the zeta potential has been suggested as a positive indicator of bacterial cell membrane damage [17, 21]. Therefore, 33 ingredients were tested for their effect on the zeta potential of all three different strains. Deepika et al. [27] observed the decrease of the zeta potential of Lactobacillus rhamnosus GG with the increase of $\mathrm{pH}$ showing the highest zeta potential of the cells over a range of $\mathrm{pH} 2-3$. The strongly acidic environment of the stomach is one of the initial hurdles in which the survivability of the bacteria is drastically reduced. The zeta potential detection of the freeze-dried bacterial cells was conducted at $\mathrm{pH} 2.5$ which mimics the acid environment of the stomach. Out of the 33 ingredients, including carbohydrates, amino acids and proteins that may play a role in preserving the cell membrane [8], Llysine was the only component showing polarization for 
A
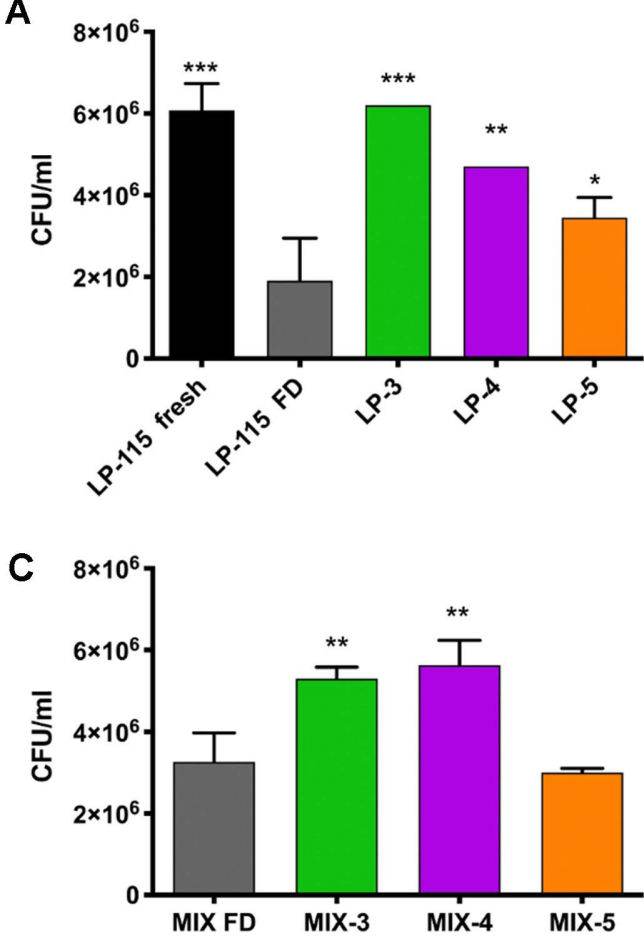

B
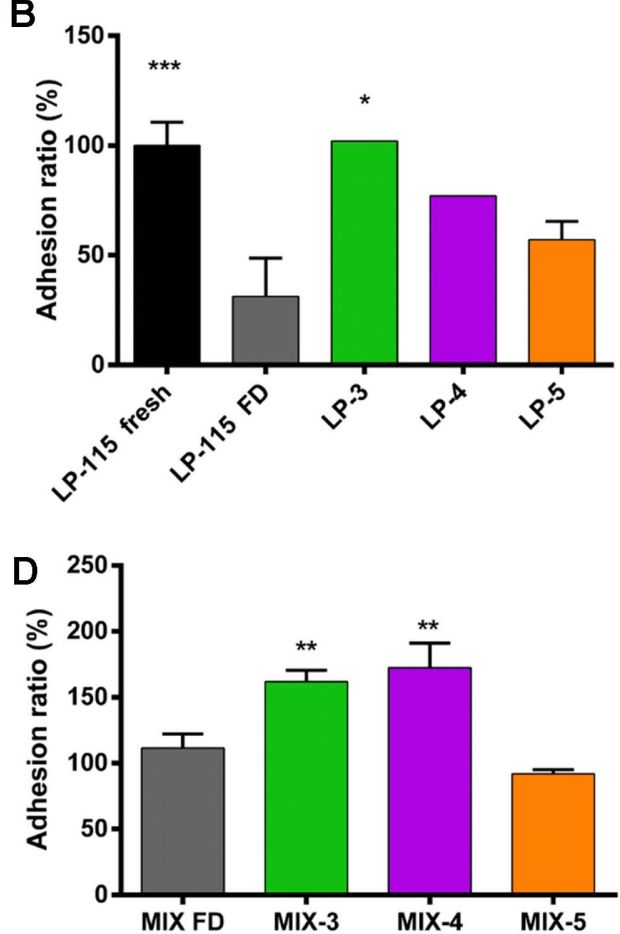

Fig. 3. Cell adhesion results to the human enterocyte-like Caco-2 cell-line as influenced by the concentration of lysine in the

Zeta-bio formulation. (A, B) Lactiplantibacillus plantarum Lp-115, (C, D) 7-strain mixture (400B). Fresh: freshly (18 h) grown bacterial cells, FD: freeze-dried bacterial cells; 3: $0.03 \mathrm{M}$ of lysine; $4: 0.04 \mathrm{M}$ of lysine; 5: $0.05 \mathrm{M}$ of lysine. Statistical analysis was performed using one-way ANOVA compared to each strain's freeze-dried (FD) sample. ${ }^{*} p<0.05,{ }^{* *} p<0.01,{ }^{* * *} p<0.001$ by Fisher's LSD test.

all three strains that were tested (Fig. 1). Furthermore, L-lysine recovered the cell adhesion ratio that was decreased due to the freeze-drying process of each strain and mixture (Fig. 2). Proline is being used in some commercial mixtures in the market. However, when comparing the data obtained with proline, a slight polarization rather than hyperpolarization or depolarization of the zeta potential appears to be essential for better cell adhesion (Fig. 2), thereby serving as strong justification for the implementation of lysine rather than proline. This was also reported by de Wouters et al. [20] when finding a negative zeta potential closer to $0 \mathrm{mV}$ to reflect a higher hydrophobicity and thereby leading to improved cell adhesion. Increased lysine concentrations resulted in higher hydrophobicity values of the cultures, suggesting a possible improvement in their adhesion potential. Therefore, achieving a negative zeta potential to maintain cell integrity and viability [17] and a slight polarization for higher cell adhesion [20] appears to be crucial for improving its functionality as a probiotic. Poly-L-lysine which is a homopolymer of L-lysine, an essential amino acid, has been proposed as a microencapsulating agent for bacterial coating that helps increase the bacterial cell viability in gastric acid conditions [28]. Besides L-lysine, other amino acids such as Lglutamic acid have also been investigated for their potential as encapsulating agents for the protection of probiotics [29].

Further research was performed to find the optimal concentration of L-lysine for the Zeta-bio formulation which is mixed with the prebiotic fructooligosaccharides (FOS). Besides enhancing the taste of the product, FOS is a well-known and commonly used prebiotic added for its prebiotic advantage and for improving the viability of probiotics due to its resistance to gastric stress [30-33]. Moreover, FOS is also known to provide beneficial health effects through the stimulation of colon bacteria producing short chain fatty acids, and for reducing weight-gain and preventing intestinal diseases [34]. FOS is also known to modulate the microbiome to a healthy state by increasing the ratio of the commensal bacteria in the human gut [35]. Furthermore, the addi- 
tion of L-lysine to FOS is known to help enhance the resistance of a strain under unbalanced osmotic conditions [36].

When the Zeta-bio formulation with different lysine concentrations $(0.01 \mathrm{M}-0.05 \mathrm{M})$ was applied to the commercial probiotic powders L. plantarum Lp-115 and the 7-strain mixture (400B), both the viability after SSDP and cell adhesion ratios were significantly higher in 0.03 $\mathrm{M}$ of lysine compared to the controls and other concentrations (Table 3 and Fig. 3). The rehydration of the probiotic lyophilizates helped reactivate cells by altering the zeta potential and increasing their viability. Complex rehydration media may play a role in promoting repair of damaged cells by providing additional nutrients, energy and essential cell components required for injured cells [37]. Furthermore, the increase in the viability and alteration of the zeta potential of the cells may improve the total cell adhesion ratio of the bacteria to the intestinal cells.

In conclusion, the application of the $0.03 \mathrm{M}$ lysinebased Zeta-bio formulation for freeze-dried probiotic products, as exemplified by Lp. plantarum Lp-115 and the 7-strain mixture (400B), can improve the viability after gastric and duodenum stress conditions and restore their functional potential by increasing of adherence to intestinal cells.

\section{Conflict of Interest}

The authors have no financial conflicts of interest to declare.

\section{References}

1. Amar J, Chabo C, Waget A, Klopp P, Vachoux C, Bermudez-Humaran LG, et al. 2011. Intestinal mucosal adherence and translocation of commensal bacteria at the early onset of type 2 diabetes: molecular mechanisms and probiotic treatment. EMBO Mol. Med. 3: 559-572.

2. Bomba A, Brandeburova A, Ricanyova J, Strojny L, Chmelarova A, Szabadosova V, et al. 2012. The role of probiotics and natural bioactive compounds in modulation of the common molecular pathways in pathogenesis of atherosclerosis and cancer. Biologia 67: 1-13.

3. Jonkers D, Penders J, Masclee A, Pierik M. 2012. Probiotics in the management of inflammatory bowel disease: A systematic review of intervention studies in adult patients. Drugs 72: 803823.

4. Kwon HK, Lee CG, So JS, Chae CS, Whang JS, Sahoo A, et al. 2010.
Generation of regulatory dendritic cells and CD4+ Foxp3+ T cells by probiotics administration suppresses immune disorders. Proc. Natl. Acad. Sci. USA 107: 2159-2164.

5. Meng XC, Stanton C, Fitzgerald GF, Daly C, Ross RP. 2008. Anhydrobiotics: the challenges of drying probiotic cultures. Food Chem. 106: 1406-1416.

6. Caselli M, Cassol F, Calo G, Holton J, Zuliani G, Gasbarrini A. 2013. Actual concept of "probiotics": is it more functional to science or business? World J. Gastroenterol. 19: 1527-1540.

7. Senz M, Keil C, Schmacht M, Palinski S, Cämmerer B, Hageböck M. 2019. Influence of media heat sterilization process on growth performance of representative strains of the genus Lactobacillus. Fermentation 5: 20.

8. Reddy KBPK, Awasthi SP, Madhu AN, Prapulla SG. 2009. Role of cryoprotectants on the viability and functional properties of probiotic lactic acid bacteria during freeze drying. Food Biotechnol. 23: 23-265.

9. Arellano K, Vazquez J, Park H, Lim J, Ji Y, Kang H, et al. 2020. Safety evaluation and whole-genome annotation of Lactobacillus plantarum strains from different sources with special focus on isolates from green tea. Probiotics Antimicrob. Proteins 12: 10571070.

10. Ahn IS, Lee CH. 2003. Kinetic studies of attachment and detachment of microbial cells from soil. Environ. Technol. 24: 411-418.

11. Hong Y, Brown DG. 2006. Cell surface acid-base properties of Escherichia coli and Bacillus brevis and variation as a function of growth phase, nitrogen source and C:N ratio. Colloids Surf. $B$. Biointerfaces 50: 112-119.

12. Silhavy TJ, Kahne D, Walker S. 2010. The bacterial cell envelope. Cold Spring Harb. Perspect. Biol. 2: a000414.

13. Dufrêne YF, Persat A. 2020. Mechanomicroiology: how bacteria sense the respond to forces. Nat. Rev. Microbiol. 18: 227-240.

14. Boonaert CJP, Rouxhet PG. 2000. Surface of lactic acid bacteria: relationships between chemical composition and physicochemical properties. Appl. Environ. Microbiol. 66: 2548-2554.

15. Kłodzinska E, Szumski M, Dziubakiewicz E, Hrynkiewicz K, Skwarek $E$, Janusz W, et al. 2010. Effect of zetapotential value on bacterial behavior during electrophoretic separation. Electrophoresis 31: 1590-1596.

16. Soon RL, Nation RL, Cockram S, Moffatt JH, Harper M, Adler B, et al. 2011. Different surface charge of colistin-susceptible and resistant Acinetobacter baumannii cells measured with zeta potential as a function of growth phase and colistin treatment. J. Antimicrob. Chemother. 66: 126-133.

17. Halder S, Yadav KK, Sarkar R, Mukherjee S, Saha P, Karmakar S, et al. 2015. Alteration of zeta potential and membrane permeability in bacteria: a study with cationic agents. SpringerPlus 4: 672 .

18. Ng W, Ting Y. 2017. Zeta potential of bacterial cells: effect of wash buffers. PeerJ Preprints 5: e110v7.

19. Cowan MM, Van der Mei HC, Stokroos I, Busscher HJ. 1992. Heterogeneity of surfaces of subgingival bacteria as detected by zeta potential measurements. J. Dent. Res. 71: 1803-1806.

20. de Wouters T, Jans C, Niederberger T, Fischer P, Rühs PA. 2015. 
Adhesion potential of intestinal microbes predicted by physicochemical characterization methods. PLoS One 10: e0136437.

21. Wilson WW, Wade MM, Holman SC, Champlin FR. 2001. Status of methods for assessing bacterial cell surface charge properties based on zeta potential measurements. J. Microbiol. Methods 43: $153-164$

22. Ji Y, Kim H, Park H, Lee J, Lee $H$, Shin $H$, et al. 2013. Functionality and safety of lactic bacterial strains from Korean kimchi. Food Control 31: 467-473.

23. Botes M, Loos B, van Reenen CA, Dicks LM. 2008. Adhesion of the probiotic strains Enterococcus mundtii ST4SA and Lactobacillus plantarum 423 to Caco-2 cells under conditions simulating the intestinal tract, and in the presence of antibiotics and antiinflammatory medicaments. Arch. Microbiol. 190: 573-584.

24. Galdeano CM, Cazorla SI, Dumit JML, Vélez E, Perdigón G. 2019. Beneficial effects of probiotic consumption on the immune system. Ann. Nutr. Metab. 74: 115-124.

25. Monteagudo-Mera A, Rastall RA, Gibson GR, Charalampopoulos D, Chatzifragkou A. 2019. Adhesion mechanisms mediated by probiotics and prebiotics and their potential impact on human health. Appl. Microbiol. Biotechnol. 103: 6463-6472.

26. Govender M, Choonara YE, Kumar P, du Toit LC, van Vuuren S, Pillay V. 2014. A review of the advancements in probiotic delivery: conventional vs. non-conventional formulations for intestinal flora supplementation. AAPS PharmSciTech 15: 29-43.

27. Deepika G, Green RJ, Frazier RA, Charalampopoulos D. 2009. Effect of growth time on the surface and adhesion properties of Lactobacillus rhamnosus GG. J. Appl. Microbiol. 107: 1230-1240.

28. Hlaing SP, Kim J, Lee J, Kwak D, Kim H, Yoo JW. 2020. Enhanced viability of probiotics against gastric acid by one-step coating process with poly-L-lysine: in vitro and in vivo evaluation.
Pharmaceutics 12: 662.

29. Karimi M, Yazdi FT, Mortazavi SA, Shahabi-Ghahfarrokhi I, Chamani J. 2020. Development of active antimicrobial poly(L-glutamic) acid-poly (L-lysine) packaging material to protect probiotic bacterium. Polym. Test. 83: 106338.

30. Rajam R, Kumar SB, Prabhasankar P, Anandharamakrishnan C. 2015. Microencapsulation of Lactobacillus plantarum MTCC 5422 in fructooligosaccharide and whey protein wall systems and its impact on noodle quality. J. Food Sci. Technol. 52: 4029-4041.

31. Śliżewska K, Kapuśniak J, Barczyńska R, Jochym K. 2012. Resistant dextrins as prebiotic. Carbohydrates-Comprehensive Studies on Glycobiology and Glycotechnology. Rijeka: InTech. 2012: 261-288.

32. Ring $\varnothing$, Olsen RE, Gifstad T, Dalmo RA, Amlund $\mathrm{H}$, Hemre Gl, et al. 2010. Prebiotics in aquaculture: a review. Aquac. Nutr. 16: 117 136.

33. Su P, Henriksson A, Mitchell H. 2007. Prebiotics enhance survival and prolong the retention period of specific probiotic inocula in an in vivo murine model. J. Appl. Microbiol. 103: 2392-2400.

34. Brownawell AM, Caers W, Gibson GR, Kendall CW, Lewis KD, Ringel $Y$, et al. 2012. Prebiotics and the health benefits of fiber: current regulatory status, future research, and goals. J. Nutr. 142: 962-974.

35. Manning TS, Gibson GR. 2004. Prebiotics. Best Pract. Res. Clin. Gastroenterol. 18: 287-298.

36. Celligoi MAPC, Dos Santos DA, Da Silva PB, Baldo C. 2016. Biotechnological applications of fructooligosaccharides in food processing industries, pp. 342-358. In Montet D, Ray RC (eds) Fermented Foods Part 1: CRC Press, FL, USA.

37. Morgan C, Vesey G. 2009. Freeze-drying of microorganisms. Encyclopedia Microbiol. 2009: 162-173. 